\title{
Determinants of nonperforming loans in the Southern Mediterranean countries
}

\author{
Saoussen Ouhibi*, Sami Hammami \\ Faculty of Economics and Management, University of Sfax, Tunisia \\ *Corresponding author E-mail:saoussenouhibi@yahoo.fr
}

\begin{abstract}
The main aim of this paper is to examine the determinants of financial soundness indicators (non-performing loans) of the banking system. There are several factors that lead to the growth or decline of non-performing loans, such as macroeconomic variables. This study uses a sample of six out often countries of the Southern Mediterranean (Tunisia, Morocco, Egypt, Lebanon, Jordan and Turkey) that were analyzed over the period of 2000 to 2012. Our result shows that the non-performing loans negatively depend on the nominal exchange rate, the consumer price index and the gross capital formation.
\end{abstract}

Keywords: Banking Sectors; Macroeconomic Determinants; Non-Performing Loans.

\section{Introduction}

The negative effects of the global financial crisis on the southern countries of the Mediterranean helped to demonstrate that the external funding sources can induce macroeconomic instability contexts to the difficulty of combining the autonomy of the monetary policy and the stability of the exchange rate, hence the risk of financial system vulnerability of these economies.

Therefore, whenever financial vulnerability is examined, the main emphasis is placed on the levels of non-performing loans. The NPL in the southern countries of the Mediterranean are increasing with an alarming rate each year (World Bank). Therefore, the main aim of the current study is to analyse the relationship between the ratio of non-performing loans (NPL) and the macroeconomic sector variables to assess the vulnerability of the banking sector.

The non-performing loan is an indicator of financial stability, as it reflects on the quality of the assets, credit risk and efficiency in the allocation of resources to productive sectors. The credit quality of the loan portfolio in most countries remained relatively stable until the financial crisis hit the global economy in 2007-2008. The average quality of the bank assets deteriorate sharply due to the global economic recession.

Common exposure to macroeconomic risk factors across banks is a source of systemic risk that influences the quality of a loan portfolio, which can be expressed as the ratio of non-performing loans to total gross loans. An increasing ratio may be a signal of deterioration in the banking sector results. In theory, we would expect the risk of credit expansion and the non-performing loans to a total loan (NPL) ratio to be procyclical within an economic cycle (Schinasi 2005).

The deterioration of the quality of the loan portfolio was the main cause of problems in the banking systems, and asset qualities are often associated with the presence of bankruptcy risk and financial crisis in both developed and developing countries .Non- perform ing loans are among the main causes of economic stagnation problems (Nkusu, 2011). The presence of these loans causes a problem in the financial sector and increases the possibility of difficulty and unpredictability in the company.

The transition economies shared a common problem: their banking sectors in the early 1990 s were characterized by a relatively small number of large state-owned institutions that had become burdened by large volumes of non-performing loans. We can point to two reasons for this: first, these countries had to deal with the issue of a large amount of inherited NPL from the past, and second new NPLs mounted up in the balance sheets of commercial banks due to a lack of experience, government intervention, inappropriate incentives for bank management and poorly designed privatization methods (Mejra Festic 2009).

\section{The empirical literature overview}

In recent years, the literature examining the non-performing loans (NPL) has attracted the attention of several researchers especially given the interest in understanding the factors responsible for the financial vulnerability.

There are many empirical literatures on macroeconomic factors that influence the non-performing loans (NPLs). These macroeconomic variables are the annual GDP growth, unemployment rates, real interest rate, money supply, inflation rate, per capita GDP, CPI, the index of stock prices, FDI, exports and the real exchange rate. 
Table 1: The empirical literature Overview

\begin{tabular}{|c|c|c|}
\hline Author(S) & Methodology and economies & Results \\
\hline Faward A and Taqodus B (2013) & $\begin{array}{l}\text { The authors used time series data to nine macroeconomic variables } \\
\text { (annual growth in GDP, unemployment rates, real interest rates, infla- } \\
\text { tion, the CPI, the real effective exchange rates, exports, industrial } \\
\text { production and FDI) over the } 1990-2011 \text { period in the case of Pakistan. }\end{array}$ & $\begin{array}{l}\text { The application of OLS for macroeconomic variables suggests that } \\
\text { GDP growth, interest rates, inflation rates, the CPI, exports and } \\
\text { industrial production are significant with non-performing loans, } \\
\text { while three variables (unemployment rate, the real effective ex- } \\
\text { change rate and FDI) are insignificant associated with non- } \\
\text { performing loans. }\end{array}$ \\
\hline $\begin{array}{l}\text { Peter Palogh } \\
(2012)\end{array}$ & $\begin{array}{l}\text { The author used Panel data to estimate the impact of the macroeco- } \\
\text { nomic environment on two indicators (nonperforming loans to total } \\
\text { gross loans and the ratio of assets of bank capital) of the banking } \\
\text { system from } 27 \text { countries of the European Union. }\end{array}$ & $\begin{array}{l}\text { The empirical analysis of banking systems in the EU reveals a } \\
\text { strong correlation between economic trends and financial sound- } \\
\text { ness indicators. This highlights the interdependence of the need for } \\
\text { cooperation between financial supervision and economic policy } \\
\text { that can lead to a reduction of systemic risk. }\end{array}$ \\
\hline Nir Klein(2013) & $\begin{array}{l}\text { The author examined the non-performing loans in Central Eastern and } \\
\text { South Eastern Europe in the period 1998- } 2011 \text {. } \\
\text { The base includes four explanatory variables at the bank (ratio of } \\
\text { equity to asset funds, equity returns, asset ratio of loans and loan } \\
\text { growth rates); three specific variables for each country (inflation, } \\
\text { changes in the exchange rate vis-à-vis the euro, and the unemployment } \\
\text { rate changes) and two global variables (GDP growth and the S \& P } \\
\text { 500). }\end{array}$ & $\begin{array}{l}\text { The results confirmed that the NPLs were found to respond to } \\
\text { macroeconomic conditions such as GDP growth, unemployment } \\
\text { and inflation. The analysis also indicated strong feedback effects } \\
\text { of the banking system on the real economy. }\end{array}$ \\
\hline Ali Shingjergji (2013) & $\begin{array}{l}\text { The author studied the relationship between non-performing loans and } \\
\text { GDP, inflation rate, unemployment rate and the interest rate using a } \\
\text { simple regression model for the case of Albanian. }\end{array}$ & $\begin{array}{l}\text { The regression analysis indicated a positive relationship between } \\
\text { GDP growth, the exchange rate Euro / All and the ratio of nonper- } \\
\text { forming loans. This result shows that over 50\% of loans in the } \\
\text { Albanian banking system are in Euro. }\end{array}$ \\
\hline $\begin{array}{l}\text { Carlos Andres OlayaBonilla } \\
(2012)\end{array}$ & $\begin{array}{l}\text { This research studies the macroeconomic determinants of non- } \\
\text { performing loans in Spain and Italy for the period from January } 2004 \\
\text { to March 2012. The macroeconomic variables are credit growth, wag- } \\
\text { es, inflation, unemployment and GDP. }\end{array}$ & $\begin{array}{l}\text { The author found that the five independent variables which used, } \\
\text { only unemployment, wages and GDP, are statistically significant. }\end{array}$ \\
\hline $\begin{array}{l}\text { M, Farhan. A, Sattar. A, H, } \\
\text { Chaudhry. F, Khalil (2012). }\end{array}$ & $\begin{array}{l}\text { The regression analysis was performed to analyze the impact of the end } \\
\text { of the independent variables (the interest rate, the energy crisis, unem- } \\
\text { ployment, inflation, GDP growth and the exchange rate) on non- } \\
\text { performing loans of the banking sector of Pakistan. }\end{array}$ & $\begin{array}{l}\text { The authors showed that the interest rate, the energy crisis, unem- } \\
\text { ployment, inflation and the exchange rate have significant positive } \\
\text { relationships with non-performing loans in the banking sector of } \\
\text { Pakistan, while GDP growth has a significant negative relation- } \\
\text { ship. }\end{array}$ \\
\hline $\begin{array}{l}\text { Roland Beck, Peter Jakubic, et } \\
\text { AnamariaPiloiu (2013). }\end{array}$ & $\begin{array}{l}\text { The authors studied the macroeconomic determinants of non- } \\
\text { performing loans of } 75 \text { countries over ten years on a panel data. In the } \\
\text { econometric models used for this analysis, the real GDP (measure of } \\
\text { macroeconomic performance), the nominal effective exchange rate, the } \\
\text { interest rate loans, stock prices and credit of all stocks are considered } \\
\text { determinants of nonperforming loans. }\end{array}$ & $\begin{array}{l}\text { Econometric analysis suggests that real GDP growth was the main } \\
\text { determinant of nonperforming loans. } \\
\text { The authors showed that evaluation of the overall risk of asset } \\
\text { quality and credit in the financial sector are important elements of } \\
\text { macroprudential supervision. }\end{array}$ \\
\hline $\begin{array}{l}\text { MejraFestic, } \\
\text { Alenka } \\
\text { Kaviller, } \\
\text { Sebastijan } \\
\text { (2011) }\end{array}$ & $\begin{array}{l}\text { The authors studied the macroeconomic sources of systemic risk in the } \\
\text { banking sectors of the five new members of the EU. } \\
\text { The authors applied the Panel regression method using the export of } \\
\text { goods and services, real GDP, fixed capital formation, FDI, disposable } \\
\text { income and compensation of employees, net foreign assets, the ratio of } \\
\text { deposit loans, the ratio of asset loans and the basic principles of Bale. } \\
\text { They used a panel regression with fixed effect and random effect for } \\
\text { the analysis. }\end{array}$ & $\begin{array}{l}\text { The results indicate that FDI in financial intermediation contrib- } \\
\text { utes to worsening of non-performing loans. Gross capital for- } \\
\text { mation contributed to the GDP growth and a reduction in bad } \\
\text { debts, export growth and industrial production has a direct effect } \\
\text { on the sustainability of the results of the banking sector in these } \\
\text { countries. }\end{array}$ \\
\hline
\end{tabular}

\section{Data and methodology}

The data set, which consists of a group of six countries of the Southern Mediterranean, is based on the annual frequency for the $2000-2012$ period and collected from the World Bank.

To evaluate the non-performing loans to total loans based on a series of macroeconomic variables, the model is given as:

NPLit $=\alpha_{0}+\alpha 1$ GDPit $+\alpha 2$ ICPit $+\alpha 3$ URit $+\alpha 4$ GCF it $+\alpha 5$ EXPit $+\alpha 6$ NERit $+\alpha 7$ FDIit $+\alpha 8$ DSit $+€$ it

Where;

NPL it: is the rate of non-performing loans calculated as percent of the total volume, of loans granted in the respective country $i$ at the moment $\mathrm{t}$.

GDPit: is the annual growth rate of Gross Domestic Production the country I at the moment $t$.

ICPit: Indices of Consumer Prices in the country i at time t.

URit: is the annual average unemployment rate calculated as a percentage of the total labour force in the respective country $i$ at time $\mathrm{t}$.

GCFit: is the Gross Capital Formation (\% of GDP) in the respective country $i$ at time $t$

EXPit: are the exports in the country $i$ at time t.

NERit: is the Nominal Exchange Rate in the country $i$ at time t.

FDIit: is the Foreign Direct Investment in country $i$ at time t.

DSit: is the Deficit/Surplus in the respective country $i$ at the moment $\mathrm{t}$. €it: stands for the estimation error.

$\alpha_{0}, \alpha 1, \alpha 2, \alpha 3, \alpha 4, \alpha 5, \alpha 6, \alpha 7, \alpha 8$ are the respective co-effcient terms.

The criteria of selecting these variables that empirically exist in the review found positive or negative influence of these variables on NPL and availability of data.

To explain the indicators of financial stability, we used the OLS regression in a general panel regression model. Thus, most of the existing studies have shown that OLS is an appropriate model to describe the determinants of non-performing loans (Faward A and B Taqodus (2013); Peter Palogh (2012); Shingjergji Ali (2013); SkaricaBruna (2013) Carlos Andres Olaya Bonilla (2012)).

The methods used in the various estimates that seek empirical evidence of a relationship between non-performing loans (source of systemic risk), and macroeconomic variables are: the analysis of co-integration, correlation and panel regression.

Before applying the OLS (Table 4), we begin our analysis with a complete description of all variables (Table 2). Then, we use the correlation matrix (Table 3 ) to check multicollinearity. The multicollinearity problem arises because of the high correlation between any explanatory variables. Two variables are positively correlated if their correlation coefficient is positive and vice versa. 


\section{Empirical results and discussion}

Descriptive statistics is used to present quantitative description of different variables (dependent and independent), such as the mean and standard deviation presented in the following table;

Table 2: Descriptive Statistics

\begin{tabular}{lllcc}
\hline variable & Mean & Standard Deviation & Minimum & Maximum \\
\hline NPL & 12.51892 & 6.829041 & 2.5 & 29.3 \\
ICP & 6.816667 & 10.00276 & -.7 & 54.9 \\
GDP & 4.596154 & 2.894304 & -5.7 & 9.4 \\
UR & 11.59067 & 2.686964 & 6.4 & 20 \\
& & & & \\
GCF & 24.17949 & 5.497918 & 15 & 38 \\
& & & & \\
EXP & 32.48718 & 11.91283 & 14 & 57 \\
D/S & -4.355556 & 3.817118 & -15 & 2.5 \\
FDI & 9.054806 & 1.561514 & 0 & 10.34335 \\
NER & .8690435 & 1.403264 & -.2006595 & 5.73 \\
\hline
\end{tabular}

The descriptive statistics of the variables used in the empirical analysis is presented in Table 2. The Export and NPL variable present a very high disparity, since its minimum value stands at $2,5 \%$ and maximum at $29,3 \%$. As far as GDP is concerned, there is a positive and negative value, indicating that, over the period 2000-2012, some countries showed a negative growth . Similary ICP, nominal exchange rate and Deficit/Surplus, show a positive and negative value. Furthermore, FDI demonstrates a minimum of $0 \%$ and a maximum of $10,34 \%$. Finally, variable UR ranges from $6,4 \%$ to $20 \%$ and GCF from $15 \%$ to $38 \%$.

In order to detect a possible relationship between the variables, we will present the various correlation coefficients in the following table to test the correlation between these variables.

Table 3: Correlation Matrix

\begin{tabular}{|c|c|c|c|c|c|c|c|c|c|}
\hline VBs & NPL & ICP & GDP & UR & GCF & EXP & $\mathrm{D} / \mathrm{S}$ & FDI & $\begin{array}{l}\mathrm{NE} \\
\mathrm{R}\end{array}$ \\
\hline $\begin{array}{l}\mathrm{NP} \\
\mathrm{L}\end{array}$ & $\begin{array}{l}1.000 \\
0\end{array}$ & & & & & & & & \\
\hline ICP & 0.04 & $\begin{array}{c}1.00 \\
00\end{array}$ & & & & & & & \\
\hline $\begin{array}{l}\text { GD } \\
P\end{array}$ & -0.21 & -0.08 & $\begin{array}{l}1.00 \\
00\end{array}$ & & & & & & \\
\hline UR & $\begin{array}{c}0.23^{*} \\
38^{*}\end{array}$ & $\begin{array}{l}- \\
0.32 \\
62 *\end{array}$ & $\begin{array}{l}- \\
0.29 \\
25^{*}\end{array}$ & $\begin{array}{l}1.00 \\
00\end{array}$ & & & & & \\
\hline $\begin{array}{l}\text { GC } \\
P\end{array}$ & $\begin{array}{l}- \\
0.402 \\
9 *\end{array}$ & $\begin{array}{c}- \\
0.34 \\
63 *\end{array}$ & $\begin{array}{l}0.29 \\
22^{*}\end{array}$ & $\begin{array}{l}- \\
0.18 \\
20\end{array}$ & $\begin{array}{l}1.00 \\
00\end{array}$ & & & & \\
\hline $\begin{array}{l}\text { Ex- } \\
\text { port }\end{array}$ & $\begin{array}{l}0.075 \\
7\end{array}$ & $\begin{array}{l}- \\
0.19 \\
25\end{array}$ & $\begin{array}{l}0.10 \\
27\end{array}$ & $\begin{array}{l}0.41 \\
67^{*}\end{array}$ & $\begin{array}{l}0.37 \\
46^{*}\end{array}$ & $\begin{array}{l}1.00 \\
00\end{array}$ & & & \\
\hline $\mathrm{D} / \mathrm{S}$ & $\begin{array}{l}- \\
0.059 \\
6\end{array}$ & $\begin{array}{l}0.14 \\
94\end{array}$ & $\begin{array}{l}0.17 \\
98\end{array}$ & $\begin{array}{l}0.01 \\
89\end{array}$ & $\begin{array}{l}0.23 \\
22 *\end{array}$ & $\begin{array}{l}0.37 \\
03 *\end{array}$ & $\begin{array}{l}1.00 \\
00\end{array}$ & & \\
\hline FDI & $\begin{array}{l}- \\
0.092 \\
4\end{array}$ & $\begin{array}{l}0.07 \\
66\end{array}$ & $\begin{array}{l}0.20 \\
32\end{array}$ & $\begin{array}{l}- \\
0.33 \\
60^{*}\end{array}$ & $\begin{array}{l}0.15 \\
16\end{array}$ & $\begin{array}{l}0.11 \\
36\end{array}$ & $\begin{array}{l}0.14 \\
46\end{array}$ & $\begin{array}{l}1.00 \\
00\end{array}$ & \\
\hline $\begin{array}{l}\mathrm{NE} \\
\mathrm{R}\end{array}$ & $\begin{array}{l}- \\
0.114 \\
6 \\
\end{array}$ & $\begin{array}{l}- \\
0.14 \\
60 \\
\end{array}$ & $\begin{array}{l}0.07 \\
57\end{array}$ & $\begin{array}{l}- \\
0.26 \\
31 * \\
\end{array}$ & $\begin{array}{l}0.10 \\
93\end{array}$ & $\begin{array}{l}- \\
0.48 \\
68^{*} \\
\end{array}$ & $\begin{array}{l}- \\
0.49 \\
47^{*}\end{array}$ & $\begin{array}{l}- \\
0.05 \\
57 \\
\end{array}$ & $\begin{array}{l}1.00 \\
00\end{array}$ \\
\hline
\end{tabular}

According to the correlation matrix table, we see that the unemployment rate is positively correlated with the non-performing loans; this is also consistent with the findings of Nir Klein (2013), Carlos Andres Olaya Bonilla (2012), M Farhan. A Sattar. A, H, Chaudhry. F, Khalil (2012).

Table 3 also shows that the gross capital formation is negatively correlated with the non-performing loans, while other macroeconomic variables (GDP, nominal exchange rate, and exports, FDI, Deficit/Surplus and IPC) are insignificant.

To identify the determinants of non-performing loans, we used the panel fixed effect model. The following table summarizes the results of the estimated regression model is estimated using Ordinary least Square.

The table below shows that three macroeconomic variables (the index of consumer prices, the exchange rate and gross capital formation) are significant with non-performing loans, while the other variables in our model (GDP, FDI, exports, unemployment and Deficit/Surplus) are insignificant.

There are direct links between non-performing loans and macroeconomic variables, the coefficient of determination (R-squared $=0$, 3181 ) shows that $31,81 \%$ of the variation in the dependent variable (non-performing loans) can be explained by the model regression.

\begin{tabular}{lllll}
\multicolumn{5}{c}{ Table 4: Results of OLS } \\
\hline Variables & Co-efficient & Standard error & t-Statistic & propability \\
\hline ICP & $-.2499703 *$ & .1476782 & -1.69 & 0.096 \\
GDP & .2308064 & .363631 & 0.63 & 0.528 \\
UR & .1695135 & .3564118 & 0.48 & 0.636 \\
GCF & $-.7092265 * *$ & .1409328 & -5.03 & 0.000 \\
EXP & .1300535 & .0877098 & 1.48 & 0.143 \\
D/S & .2067832 & .2070385 & 1.00 & 0.322 \\
FDI & -.8612075 & 1.01332 & -0.85 & 0.399 \\
NER & $.794426 *$ & .4615228 & 1.72 & 0.090 \\
Cons & 31.65706 & 11.61474 & 2.73 & 0.008 \\
R-squared $=0.3181$ & & & \\
F statistic $=7.42$ & & & \\
Prob(F-Statistic) $=0.0000$ & & & \\
\hline ***significant at $1 \%$ & & & \\
**significant at 5\% $5 \%$ & \\
*significant at $10 \%$ & &
\end{tabular}

This estimate indicates that inflation adversely affects nonperforming loans. Inflation can have a negative impact on the quality of bank assets in the case of developed countries and positive in the emerging economies of Latin America (Peter Palogh 2012).

Table 4 shows that if the consumer prices index grows by 1 percent, non-performing loan's decrease by $0,24 \%$. The results of OLS for the growth of the consumer price index are consistent with the findings of the existing studies (Peter Palogh (2012) Güngör Turan and Arjeta Koskija (2014); Skarica Bruna (2014)) which justify the negative relationship between non-performing loans and the CPI.

Regarding the exchange rate, we found a significant positive relationship with non-performing loans, which suggests that whenever there is a deteriorating international competitiveness of the national economy, the level of non-performing loan's increases. This seems to be consistent with the results of MunibBadar and Atiy javid Yasmin (2013); Tarron Khemraj and Sukrishnalall Pasha (2012); Shingjergji Ali (2013); M Farhan. A Sattar. A, H, Chaudhry. F, Khalil (2012).

According to previous studies, there is a significant negative relationship between non-performing loans and gross capital formation (Mejra Festic, Alenka Kaviller, Sebastijan (2011); Mejra Fistic (2009)). Similar to these studies, our results mean that the increase in gross capital formation is susceptible to cause a reduction in non-performing loan portfolios.

\section{Conclusion}

After assessing systemic risk and refining the impact of macroprudential policies to ensure financial stability, it is essential to identify the variables that can affect the non-performing loans for countries of the southern Mediterranean.

The banking system of the southern Mediterranean countries faces many challenges, such as problems caused by the economic crisis, revolutions (Tunisia, Egypt) moreover; the fact that banks are not cautious about providing loans resulted in an increase in nonperforming loans (NPLs). These are the most important source of systemic risk in the financial system and the spread of macroeconomic contagion.

In this situation, the empirical results show that the consumer prices index, the exchange rate and gross capital formation are significant with non-performing loans, while GDP, FDI, exports, the rate unemployment and surplus / deficit treasure are insignificant.

To conclude, we can say that the banking system of the southern Mediterranean countries reveals a correlation between economic 
trends and the indicator of financial soundness (PNP). This highlights the interdependence of the need for cooperation between financial supervision and monetary policy as a new space for reflection, which can lead to a reduction of systemic risk and therefore to financial stability.

\section{References}

[1] Ali, S. (2013), « The Impact of Macroeconomic Variables on the NonPerforming Loans in the Albanian Banking System during 2005 $2012 »$, Academic Journal of Interdisciplinary Studies, Vol. 2, No. 9 , pp .335-339.

[2] Carlos, A., Olaya Bonilla (2012): «Macroeconomic determinants of the Non-Performing Loans in Spain and Italy », Department of Economics University of Leicester.

[3] Dimitrios, P. L., Angelos, T.V., Vasilios, L.M. (2011), « Macroeconomic and bank-specific determinants of non-performing loans in Greece: A comparative study of mortgage, business and consumer loan portfolios », Journal of Banking \& Finance,

[4] Faward, A., Taqodus, B. (2013), « Explanatory Power of Bank Specific Variables as Determinants of Non-Performing Loans: Evidence form Pakistan Banking Sector », World Applied Sciences Journal, Vol .22, No.9, pp. 1220-1231.

[5] Güngör, T., Arjeta, K. (2014), « Nonperforming Loans in Albania », Academic Journal of interdisciplinary studies, vol.3, No.3, pp.491-500.

[6] Khemraj, T., Sukrishnalall,P.(2009), «The Determinants of NonPerforming Loans: An Econometric Case Study of Guyana », Munich Personal RePEc Archive

[7] M, Nkusu (2011), « Nonperforming Loans and Macro financial Vulnerabilities in Advanced Economies", IMF Working paper, WP/11/161, July, 2011.

[8] Mejra, F. (2009), «Financial Stability in the Baltics », Journal of Economics and Finance, vol.59, No6, pp.

[9] Muhamed, F. A, Sattar. A, H, Chaudhry. F, Khalil (2012), «Economic Determinants of Non-Performing Loans: Perception of Pakistani Bankers », European journal of business and Management, vol 4, No 19, 2012.

[10]Munib, B., Atiya, J. Y. (2013), « Impact of Macroeconomic Forces on Nonperforming Loans: An Empirical Study of Commercial Banks in Pakistan », Wseas Transactions on Business, Issue 1, Vol.10,pp 40-48.

[11]Nir, K. (2013), « Non-Performing Loans in CESEE: Determinants and Impact on Macroeconomic Performance », IMF Working Paper, Vol .13, No.72.

[12]Peter, P. (2012), « Macro prudential supervision tools in the European system » Procedia Economics and Finance, vol. 3, pp. 642-647.

[13] Garry, J.Schinasi (2005): «préserver la stabilité financière », le Fonds monétaire international, dossiers économiques No.36.

[14]Skarica, B. (2014), « Determinants of non-performing loans in Central and Eastern European countries », financial theory and practice, Vol.38, No. 1, pp.37-59. 